\title{
Social Entrepreneurship in Higher Technology Education Students: Gender Analysis
}

\section{Emprendimiento Social en Estudiantes de Educación Superior Tecnológica: análisis de género. Yessica García Hernández ${ }^{a}$, Jessica Mendoza Moheno ${ }^{b}$ Brenda Midhely García Ortíz ${ }^{c}$}

\begin{abstract}
:
The topic of social entrepreneurship is of great importance due to the diverse problems that society faces, which require the development of effective projects with a social conscience that is oriented to contribute to community well-being. The aim of this research was to analyse the social entrepreneurial intentions of students from the business area in a higher education institution, with the purpose of identifying significant differences regarding gender. The study is empirical, descriptive, and exploratory, using a quantitative approach. The sample consisted of 228 students, of which $45.61 \%$ are male and $54.39 \%$ are female. The statistical method was applied through the t-student test, which allows us to accept the hypothesis that there is a significant difference in the social entrepreneurial intentions between men and women.
\end{abstract}

Keywords:

Social Entrepreneurship, students, gender

\section{Resumen:}

El tema de Emprendimiento Social es de gran importancia debido a las diversas problemáticas a las que se enfrenta la sociedad, las cuales requieren del desarrollo de proyectos efectivos con una conciencia social que se oriente a contribuir al bienestar comunitario. El objetivo de la investigación fue analizar la Intención de Emprendimiento Social en los estudiantes del área empresarial en una institución de educación superior tecnológica con la finalidad de identificar diferencias significativas respecto al género. El estudio es empírico, de enfoque cuantitativo, con alcance descriptivo y explicativo. Se consideró una muestra de 228 estudiantes, de los cuales el $45.61 \%$ son hombres y el $54.39 \%$ mujeres. Se aplicó el método estadístico mediante la prueba de t-student, que permite aceptar la hipótesis de que existe diferencia significativa en la intención de emprendimiento social entre hombres y mujeres.

\section{Palabras Clave:}

Emprendimiento social, estudiantes, género

\section{Introduction}

In recent years, the topic of social entrepreneurship has been part of the analysis in the academic, research and public policy domains, reason why higher Education institutions highlight its importance and guide their efforts in promoting social projects with the purpose of fulfilling this social function. In this way, they seek to develop in their students personal, social and innovative aspects that can solve problems, with a social approach, prioritizing the general well-being rather than obtaining utilities. Therefore, many diverse international organizations such as UNESCO (2009) are encouraging Higher
Education Institutions to incorporate entrepreneurial education to anticipate and respond to social needs, as part of their social function [1].

Likewise, it is incredibly important to mention that in the last few years, Latin America and México have achieved a significant increase in female participation in the development of entrepreneurial projects. This participation can be facilitated by factors such as access to education, greater access to the job market, the economic environment, and changes in family structure. However, the figures are not the same for women as they are for men [2].

Profesora-Investigadora, Tecnológico Nacional de México, Instituto Tecnológico Superior del Oriente del Estado de Hidalgo, http://orcid.org/0000-0002-4482-7275, Email: yessica.garher@gmail.com

b Profesora-Investigadora, Universidad Autónoma del Estado de Hidalgo, Instituto de Ciencias Económico-Administrativas, http://orcid.org/0000-0003-3947-0256,Email: jessica.mendoza.moheno@gmail.com

Profesora-Investigadora, Tecnológico Nacional de México, Instituto Tecnológico Superior del Oriente del Estado de Hidalgo, https://orcid.org/0000-0002-8197-6085, Email: bgarcia@itesa.edu.mx 
México faces many challenges, especially unemployment that affects a big part of its population, particularly people with higher education degrees, as a result social entrepreneurship can be considered as an important source of employment.

Similarly, it is a fact that in México there are fewer entrepreneur women. And those who decide to undertake it, face great challenges to create, maintain and consolidate their companies [3].

Consequently, a large number of challenges demand that young university students consider the opportunity to contribute to society with all of their talents, skills, abilities, intelligence, and strong will to develop as future entrepreneurs [4].

In México, half of unemployed population consists of people between 15 and 29 years old, while the other remaining half is divided into three groups that include the rest of young adults, adults and the elderly. Therefore, the unemployment rate among the youth is significantly higher than the general rate. This means that from all the economically active population only $3.4 \%$ is unemployed, whereas among the

economically active youth population the rate rises

up to $6.0 \%$ (ENOE, 2019) [5].

The above data indicates a great opportunity

so that Higher Education Institutions

endorse their commitment to contribute with academic models focused in strengthening social entrepreneurship, thus fulfilling their mission and vision of social responsibility, specifically in the area of technologic higher education. Therefore, social entrepreneurship can be considered as a viable option for business graduates to become agents of change who are able to visualize this alternative as an area of opportunity. Also, to help them overcome the paradigm that establishes that the training they receive is mainly technological; and traditionally, they are guided to enhance their creative talent in order to generate valuable ideas with the main goal of maximizing economic profit.

Yet, the lack of empirical research about social entrepreneurial intentions among university students brings up the opportunity to discover new knowledge around the subject that may lead Higher Education Institutions (IES) towards the strengthening of human capital, social entrepreneurship culture and social innovation.

For all the above, the objective of this research is to analyse the social entrepreneurship intentions among the business students in a higher technological education institution where the main goal is to identify the differences between genders.

The paper is structured as follows: after this introduction, there is a literature review, following with the methodology, the results and finally, the conclusions.

\section{Literature review}

According to the literature review, there are many diverse entrepreneurship classifications. One of them is based on the objective, for example: those markets that seek maximization of a profit, and those social entrepreneurships to assist social interests. In other words, those whose main motivation is altruism or those in which the entrepreneur's motivation is to help.

Likewise, depending on the self-sufficiency degree they are classified as social market ventures and non-market ventures. In the case of the first, they may be considered as individual or collective, and if they generate income and cover their costs, they may be profit-seeking or not. Regarding non-market ones, they do not cover costs, since they depend on public funding, such is the case of traditional NGOs (Non-Governmental Organizations) or foundations [6].

To get into the conceptualization of social entrepreneurship, it is necessary to refer to the social economy. This has become a relevant issue because of its potential to contribute to job creation, social inclusion and development of the communities, because of its orientation to the production practices, distribution, circulation and consumption in such a way as that the sustenance of all is ensured, which is equivalent to the elimination of poverty and its causes [7].

Regarding education in social entrepreneurship, it is seen as necessary to promote skills that promote creativity, imagination, critical thinking, collaboration, proactivity, and teamwork aligned with self-esteem and confidence [8] [9] [10].

Several authors have defined the social entrepreneur as a person who seeks to achieve a social mission, through the use of management tools that allow them to respond to social problems and business challenges. Therefore, their main characteristics are oriented to be agents of change that generate and foster social values. Likewise, they have the ability to recognize new opportunities at the service of their mission [11] [12].

Another concept of social entrepreneur establishes that an entrepreneur is capable of proposing solutions to the problems of an organization, strengthening business opportunities [13].

The social entrepreneur is also defined as a person who detects an opportunity and satisfies a need that has not been fulfilled by the State, as they show the ability to gather resources, such as money, volunteers and other assets, with the purpose of generating social change [14].

Some aspects that also define a social entrepreneur refer to having a highly differentiated profile articulated with the objectives of sustainable development, which causes the majority of students to get involved in social or responsibility activities. [15].

It is also considered that aspects such as educational level, age and gender are some of the determinants [16].

Similarly, it is considered that social entrepreneurs are agents of social change, with a particular profile linked to the social dimension, because they generate benefits to society above commercial or financial ones (16).

As for the importance of entrepreneurship, it aims to strengthen the management skills of students, in order to enable them to create their own employment and build their sensitivity towards society. This also helps develop skills to identify opportunities in problems and design organizational strategies to solve them [17].

In México, social entrepreneurship is important, as it is considered an alternative to overcome lags, especially in emerging countries, where governments have greater budgetary restrictions to address problems, in such a way that the sustainable value for society prevails [18] [19].

However, the advancement of social entrepreneurship has been slower compared to entrepreneurship with economic purposes, although initiatives have been generated for its development, 
highlighting the impulse of educational institutions such as the Universidad Nacional Autónoma de México or the Instituto Tecnológico y de Estudios Superiores de Monterrey [18] [20]. It is important to specify that promoting the social economy is not a simple task and requires shared responsibility between higher education institutions, the Government, and civil society that must strengthen academic training and motivation for social entrepreneurship projects [21].

With the above information, it can be established that the topic of social entrepreneurship is a topic that has become relevant over time and specifically in the field of higher education, as it is part of the training of students who will be inserted in the future in the labour market or they will undertake a project or idea [22].

Therefore, to understand the present work, it is important to specify the study variable called gender, which is defined as the social construction of the feminine and the masculine based on the biological differences between the sexes and refers, more broadly, to the existence of a system of gender relations [23]. Another concept considers gender as an impact factor, both in the decision to undertake entrepreneurship or in the intention to do so, as well as in the process of identifying opportunities to start a business activity [24]

Likewise, it is established that given the incorporation of businesswomen into economic development and job creation as a consequence of their differences, mainly with respect to the way of acting and behaving with respect to the male gender [25]. Finally, current entrepreneurship studies address the differences in terms of sociodemographic characteristics or the differences in entrepreneurship between men and women [26]. That is how, as from the review of the literature the following hypothesis arises:

H1: There is a significant difference in the mean scores of the intention of social entrepreneurship with respect to gender

\section{Methodology}

The research is basic, cross-sectional, with a quantitative approach, descriptive and explanatory scope. The student population is comprised of the students enrolled in the undergraduate programs of Business Management Engineering and Administration, considering a population of 559 university students, for which we proceeded to calculate a statistical sample for finite populations , considering an error $5 \%$ and $95 \%$ success, as well as a value of $\mathrm{z}=1.96$, this result suggests a sample of 228 students.

Once the sample was determined, the questionnaire available in google forms was sent by email to students of the different semesters by email.

As a technique for data collection a survey was applied, and the instrument of collection information is the adaptation of the questionnaire Social Entrepreneurship, which was subjected to statistical analysis obtaining a global Cronbach's alpha of 0791. The instrument is made up of three sections, the first one provides information on the sociodemographic variables of: gender, age, marital status and semester. The second part is made up of six items that measure general aspects of Social Entrepreneurship, using the Likert-type scale with the following values: 1. Not at all important 2. Not very important 3 .
Important 4. Very important. Finally, the third part includes 30 items that measure the Profile of Social Entrepreneurship (personal, social and innovative aspects), which were evaluated with the scale of five response options: 1 . Strongly disagree 2 . Disagree 3. Undecided 4 Agree 5. Strongly agree [27]. Once applied surveys, information was integrated into a database, processing and analysing data in the Statistical Package for Social Sciences (SPSS) version 22

Subsequently, the descriptive statistics were generated for the first two sections of the questionnaire. To make the contrasting of the research hypothesis raised was applied the statistical tool t student, because it is intended to identify whether there is a significant difference from the average score of the intention of social entrepreneurship of students regarding gender.

\section{Results}

As part of the results, it is identified that $45.61 \%$ of the participating students are male and $54.39 \%$ female, observing that a higher percentage predominate women, which may be due to the fact that in these educative programs of Business Management Engineering and bachelor Administration, historically the population is higher for women, as can be seen in Graph 1.

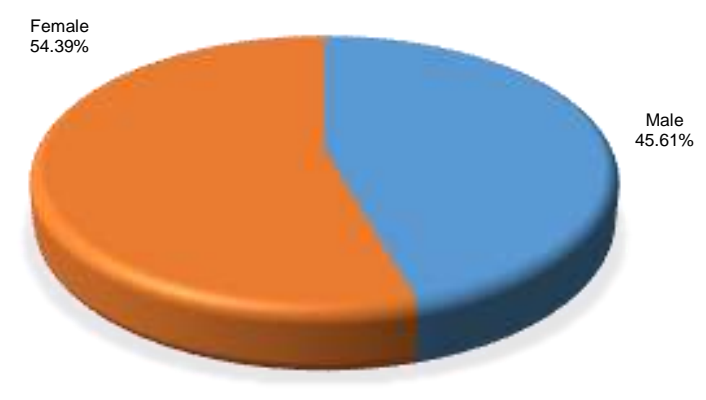

Graph 1

Gender of respondants. Source: own elaboration, based on SPSS 22

Table 1 presents the results by gender of the general aspects of social entrepreneurship, observing that in terms of academic or technical training in social entrepreneurship, the management of skills and qualifications of social entrepreneurship, the ability to identify the various financing sources, networking skills and ensuring the permanence of volunteers for men and women show that it is important although a higher percentage is reflected in the female gender; while awareness and sensitivity to social needs is considered very important, also in a higher proportion for women.

Table 1.

General aspects of social entrepreneurship 


\begin{tabular}{|c|c|c|c|c|}
\hline \multirow{2}{*}{$\frac{\text { Description }}{\text { Gender }}$} & \multicolumn{2}{|c|}{$\begin{array}{l}\text { Academic or technical training } \\
\text { of social entrepreneurship } \\
\text { within the field of social } \\
\text { business. }\end{array}$} & \multicolumn{2}{|c|}{$\begin{array}{l}\text { Mansgement of skills and } \\
\text { qualifications of social } \\
\text { entrepreneurship. }\end{array}$} \\
\hline & Male & Female & Male & Female \\
\hline $\begin{array}{l}\text { Non important } \\
\text { A bit important } \\
\text { Important } \\
\text { Highly important } \\
\text { Total } \\
\end{array}$ & $\begin{array}{l}0.00 \% \\
3.95 \% \\
22.81 \% \\
18.86 \% \\
45.61 \% \\
\end{array}$ & $\begin{array}{c}0.88 \% \\
7.46 \% \\
29.39 \% \\
16.67 \% \\
54.39 \% \\
\end{array}$ & $\begin{array}{c}0.00 \% \\
3.07 \% \\
21.49 \% \\
21.05 \% \\
45.61 \% \\
\end{array}$ & $\begin{array}{r}0.88 \% \\
4.82 \% \\
22.37 \% \\
26.32 \% \\
54.39 \% \\
\end{array}$ \\
\hline Description & \multicolumn{2}{|c|}{$\begin{array}{l}\text { Ability to identify the various } \\
\text { financing instruments and } \\
\text { resources. }\end{array}$} & \multicolumn{2}{|c|}{$\begin{array}{l}\text { Networking skills (network of } \\
\text { professional contacts) of the } \\
\text { social entrepreneur. }\end{array}$} \\
\hline $\begin{array}{c}\text { Gender } \\
\text { Non important } \\
\text { A bit important } \\
\text { Important } \\
\text { Highly important } \\
\text { Total }\end{array}$ & $\begin{array}{c}\text { Male } \\
0.00 \% \\
3.95 \% \\
21.49 \% \\
20.18 \% \\
45.61 \% \\
\end{array}$ & $\begin{array}{c}\text { Female } \\
0.88 \% \\
2.63 \% \\
21.49 \% \\
29.39 \% \\
54.39 \%\end{array}$ & $\begin{array}{c}\text { Male } \\
0.00 \% \\
7.46 \% \\
23.25 \% \\
14.91 \% \\
45.61 \% \\
\end{array}$ & $\begin{array}{l}\text { Female } \\
1.32 \% \\
6.14 \% \\
25.88 \% \\
21.05 \% \\
54.39 \% \\
\end{array}$ \\
\hline Description & \multicolumn{2}{|c|}{$\begin{array}{l}\text { Awareness and sensitivity of } \\
\text { the needs of socievy. }\end{array}$} & \multicolumn{2}{|c|}{$\begin{array}{l}\text { Ensure the arailability of } \\
\text { motivated volunteers and } \\
\text { collaborators }\end{array}$} \\
\hline $\begin{array}{c}\text { Gender } \\
\text { Non important } \\
\text { A bit important } \\
\text { Important } \\
\text { Highly important } \\
\text { Total }\end{array}$ & $\begin{array}{c}\text { Male } \\
0.43 \% \\
4.82 \% \\
20.18 \% \\
20.18 \% \\
45.61 \% \\
\end{array}$ & $\begin{array}{c}\text { Female } \\
0.88 \% \\
4.82 \% \\
14.04 \% \\
34.65 \% \\
54.39 \% \\
\end{array}$ & $\begin{array}{c}\text { Male } \\
0.44 \% \\
5.70 \% \\
23.68 \% \\
15.79 \% \\
45.61 \% \\
\end{array}$ & $\begin{array}{c}\text { Female } \\
0.44 \% \\
4.82 \% \\
20.61 \% \\
28.07 \% \\
53.95 \% \\
\end{array}$ \\
\hline
\end{tabular}

Source: own elaboration, based on SPSS 22.

On the other hand, as a result of the descriptive analysis in Table 2 and Graph 2, the mean scores obtained are shown in the personal, social and innovative aspects are shown. In women, the mean scores are placed in the following order: social aspects (4.1984), personal aspects (4.1576), innovative aspects (3.9879). Regarding men, the data are presented according to the following: personal aspects (4.1805), innovative aspects (4.0713), social aspects (4.0365). With the above data, it can be said that in personal and innovative aspects, men have a higher average score; while in social aspects, the result is higher in the female gender. As a global result of the intention of social entrepreneurship, the mean scores reflect that it is higher in women (4.1146) and in men (4.1051).

Table 2.

General aspects of social entrepreneurship.

\begin{tabular}{ccccccc}
\hline Dimensión & Gender & $\mathrm{N}$ & Mean & $\begin{array}{c}\text { Deviation } \\
\text { standard }\end{array}$ & Minium & Maximun \\
\hline Personal aspects & Male & 104 & 4.1805 & 0.34680 & 3.0769 & 4.9231 \\
& Female & 124 & 4.1576 & 0.39234 & 3.0769 & 4.9231 \\
Social aspects & Male & 104 & 4.0635 & 0.53482 & 2.0000 & 5.0000 \\
& Female & 124 & 4.1984 & 0.56597 & 2.6000 & 5.0000 \\
Innovative aspects & Male & 104 & 4.0713 & 0.41226 & 2.8333 & 5.0000 \\
& Female & 124 & 3.9879 & 0.52594 & 2.2500 & 5.0000 \\
Intention of social & Male & 104 & 4.1051 & 0.34207 & 2.9423 & 4.7197 \\
entrepreneurship & Female & 124 & 4.1146 & 0.40342 & 3.1962 & 4.9487 \\
\hline
\end{tabular}

Source: own elaboration, based on SPSS 22.

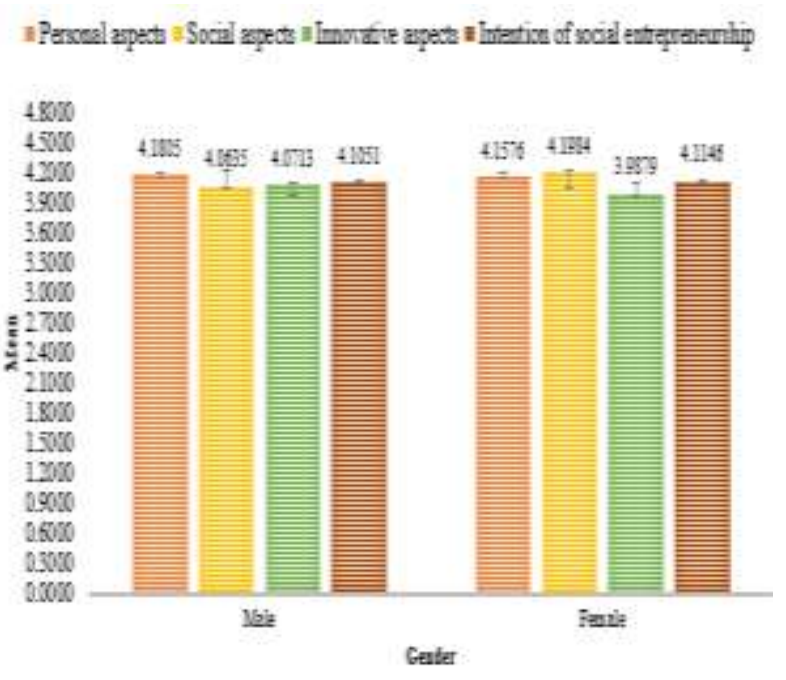

Graph 2.

Average scores of the dimensions of social entrepreneurship. Source: own elaboration, based on SPSS 22

On the other hand, to contrast the hypothesis that establishes: H1: There is a significant difference in the mean scores of the intention of social entrepreneurship with respect to gender.

To contrast the hypothesis, the statistical t- student test tool was used with the intention of analysing the differences in the mean scores for independent samples, in this case of men and women. The results indicate a value of 4,1051 for men and 4,146 for women, observing that the value of $F$ is 5.635 as well as $p=0.018$, which shows the difference in the mean scores of the intention of social entrepreneurship, which is significant, therefore, the hypothesis is accepted, the results are presented in Table 3 .

Table 3.

$\mathrm{T}$-student test for independent samples.

\begin{tabular}{llcccccc} 
& & \multicolumn{7}{c}{$\begin{array}{c}\text { Deviation } \\
\text { Variable }\end{array}$} & Gender & $\mathrm{N}$ & Mean & standard & Average & $\mathrm{F}$ & Sig. \\
\hline $\begin{array}{l}\text { Intention of social } \\
\text { entrepreneurship }\end{array}$ & Male & 104 & 4.1051 & 0.34207 & 0.03354 & & \\
\hline
\end{tabular}

Source: own elaboration, based on SPSS 22.

The results allow to define that every day greater participation of women is observed both in access to education and development as entrepreneurs, which is confirmed in this study to accept the hypothesis that there is significant differences in the entrepreneurship intention of men and women, which may be due to the work of public agencies and institutions, which have implemented strategies to develop such activities and that in recent years various opportunities have been generated for women that have allowed them to position themselves in this scope and have a greater intention of social entrepreneurship. Likewise, the results are different from those presented in the study entitled Motivations to undertake: an analysis of differences between men and women, which establishes that although entrepreneurial activity by women has increased, it is lower than that of men, mainly due to two 
fundamental barriers: external (related to the environment) and personal (sociodemographic and perception aspects) [28].

Moreover, in a study carried out from the gender perspective, it is considered that this variable has gained importance in recent years, as a conclusion they establish that the intention of entrepreneurship of male students is greater, which is contrary to the results of the present study [29].

Also, in the work carried out with university students from Almeria, it is detected that there were statistically significant differences in the variable desirability towards entrepreneurship, being the male gender the manifestation of a greater intention of entrepreneurship, which is contrary to the results of the present study.

This may be due to the fact that entrepreneurship is not a gender issue, however, the efforts made by the academy and the government can have a positive effect on the entrepreneurship intention of women, which has been reflected in the increase in their participation [30].

However, in another study carried out in Spain, which consisted of studying the predictive variables of the intention to undertake according to gender carried out with university students from the University of La Laguna from the perspective of the Theory of Planned Behaviour, it was found that there are differences in the predictive variables of the intention to undertake [31].

\section{Conclusions}

Social entrepreneurship is a topic that has generated strong interest in the academic community and the government, the role played by Higher Education Institutions (IES) is indisputable, as they are the instance in which students and future professionals develop the necessary competencies and skills that help to generate entrepreneurial activity with a social focus. In this research, the objective of: analyzing the Intention of Social Entrepreneurship in students of the business area in an institution of higher technological education was achieved in order to identify significant differences with respect to gender. Greater participation of women is observed in the study sample, likewise, that the mean scores of the dimensions of personal and innovative aspects is higher in men, while in the social factors it is higher in women. Regarding the intention of social entrepreneurship, it is defined that the average score is higher in the female gender compared to the male gender, this difference is significant, which allows accepting the hypothesis.

In general, with the results obtained, it can be defined that each day a greater participation of women is observed both in access to education and in business development, which is confirmed in the present study by accepting the hypothesis that indicates that there is a significant difference in the entrepreneurship intention of men and women, which in this case is higher in women, which may be due to the work carried out in recent years by public agencies and institutions, which have implemented strategies to develop such activities equitably.

\section{Thanks}

The collaboration of the students is appreciated: Diana Lizbeth Ortega Ugalde and Donagy Ramírez Vera.

\section{Reference sources}

[1] UNESCO (2009). Organización de las Naciones Unidas para la Educación, la Ciencia y la Cultura (UNESCO). World Conference on Higher Education: The New Dynamics of Higher Education and Research for Societal Change and Development. Recuperado de http://unesdoc.unesco.org/images/0018/001832/183277e. pdf

[2] Guzmán, J. y Rodríguez, M.J. (2008). Comportamiento de las mujeres empresarias: una visión global. Revista de Economía Mundial, 18, 381-392.

[3] Organización para la Cooperación y el Desarrollo Económicos (OECD) (2019). Resultados y relevancia para el mercado laboral, 2019. Recuperado de: https://www.oecd.org/centrodemexico/medios/educacion _superior_en_mexico.pdf

[4] Borrayo, C.L., Valdez, A. y Delgado, B. (2019). Cultura emprendedora en jóvenes universitarios de Guadalajara, México. Revista de Ciencias Sociales, 25(3), 72-87. doi: 10.31876/rcs.v26i3

[5] Encuesta Nacional de Empleo (ENOE) (2016). Encuesta Nacio4nal de Empleo y Ocupación (ENOE). Recuperado de: https://www.inegi.org.mx/temas/empleo/

[6] Santos, F. J., Barroso, M. y Guzmán, C. (2013). La economía global y los emprendimientos sociales. Revista de Economía Mundial, 35, 177-196.

[7] Castelao, M.E. (2016). Las políticas públicas y su visión de la economía social y solidaria en Argentina. Revista Mexicana de Ciencias Políticas y Sociales, 61(227), 349378. doi: 10.1016/S0185-1918(16)30032-0

[8] Korsgaard, S. (2011). Opportunity formation in social entrepreneurship. Journal of Enterprising Communities: People and places in the global economy, 5 (4), 265285.

[9] Pache, A.C. y Chowdhury, I. (2012). Social entrepreneurs as institutionally embedded entrepreneurs: Toward a new model of social entrepreneurship education. Academy of Management Learning \& Education, 11(3) 494-510.

[10] Sánchez, J.C. (2013). The impact of an Entrepreneurship Education Program on entrepreneurial competencies and Intention. Journal of Small Business Management, 51(3), 447-465.

[11] Welsh, D. H. B. y Krueger, N. (2012) The evolution of social entrepreneurship: what have we learned? Journal of Technology Management in China, 7(3), 270-290.

[12] Moreau, C. y Mertens, S. (2013) Managers' competences in social enterprises: which specificities? Social Enterprise Journal, 9 (2), 164-183.

[13] Shane, S. (2000). Prior knowledge and the discovery of entrepreneurial opportunities Organization Science, 11 (4), 448-469. 
[14] Thompson, J., Alvy, G., y Lees, A. (2000). Social entrepreneurship - a new look at the people and the potential. Management Decision, 38(5), 328-338.

[15] Melián, A. (2011). Las empresas se inserción sociolaboral creadas por emprendedores sociales. Un análisis Delphi. En: Sanchis, J.R. (dir.).

Emprendimiento, Economía Social y Empleo. Ed. IUDESCOOP. Emprendimiento social y empresas de inserción.

[16] Melián, A., Campos, V. y Sanchis, J. R. (2011). Emprendimiento social y empresas de inserción en España. Aplicación del método DELPHI para la determinación del perfil emprendedor y las empresas sociales creadas por emprendedores. REVESCO, 106, 150-172.

[17] Fournier, A. N. (2011). Emprendimiento social. Documentos de investigación. Administración de Empresas, 6, Ediciones Fundación Universidad.

[18] Becerra, M. E., Cortés, E. M., Malacara, A. R. y Alegría, N. L. (2014). Factores detonadores del Emprendimiento Social, base para el análisis de casos de éxito. International Review of Business Research Papers, 10(3), 134- 156.

[19] Moreira, P. y Urriolagoitia, L. (2011). El emprendimiento social. Revista Española del Tercer Sector, 17, 17-40.

[20] Moreno, K. (2017). La apuesta de México al emprendimiento social: Hult Prize, el "Premio Nobel de los estudiantes. Muuch' xíimbal. 139-154.

[21] Rodríguez Gómez, C. G. (2016). Panorama de programas académicos y espacios de emprendimiento en algunas universidades de México en relación con el sector de la economía social. (Tesis inédita de maestría). Universidad Iberoamericana de Puebla.

[22] Amador, M. L., García, Y. y Gutiérrez, G. (2019). Intención emprendedora de estudiantes respecto al género de un tecnológico en Hidalgo, México. Revista Iberoamericana de Ciencias, 6(4), 20-34.

[23] Espino, A. 2005. Un Marco de Análisis para el Fomento de las Políticas de Desarrollo Productivo con Enfoque de Género. Santiago de Chile: CEPAL.

[24] DeTienne D.R. y Chandler, G.N. (2007). The Role of Gender in Opportunity Identification, Entrepreneurship Theory and Practice, 31(3), 365-386. doi: 10.1111/j.1540-6520.2007.00178.x

[25] Verheul, I. Van Stel, A. J. y Thurik, A. R. (2004). Explaining female and male entrepreneurship across 29 countries. Entrepreneurship and Regional Development, 1-32.

[26] Castiblanco, S.E. 2013. La Construcción de la Categoría de Emprendimiento Femenino. Revista Facultad de Ciencias Económicas: Investigación y Reflexión, 21(2), 53-66.

[27] Capella, C., Gil, J., Martí, M. y Ruiz-Bernardo, P. (2016). Construcción de un cuestionario para medir el emprendimiento social en educación física. Pedagogía Social. Revista Interuniversitaria, 28 169-188. doi:10.7179/PsRI_2016.28.13

[28] López-Fernández, Macarena; Romero-Fernández, Pedro Miguel; Díaz Carrión, Rosalía (2012). Motivaciones para emprender: un análisis de diferencias entre hombres y mujeres. Revista Economía Industrial, 383, 75-84.
[29] De Jorge, J. (2013). Análisis de los factores que influyen en la intención emprendedora de los estudiantes universitarios. Caracciolos, 1(1), 1-12.

[30] Ruiz, J., Rojas, A., y Suárez, A. (2008). Actitudes de los estudiantes universitarios de Andalucía ante la creación de empresas. Cádiz: Servicio de Publicaciones de la Universidad de Cádiz.

[31] Ruiz De La Rosa, C.I.R., García-Rodríguez, F. \& Delgado, N. (2014). Condicionantes de la intención emprendedora en el alumnado universitario: un análisis desde la perspectiva de género. Revista de Estudios Empresariales. Segunda Época, 2, 81-96 